\title{
SODIUM DEPLETION AND RENAL CONSERVATION OF WATER *
}

\author{
By GEORGE P. BAKER, $\dagger$ HOWARD LEVITIN $\ddagger$ AND FRANKLIN H. EPSTEIN § \\ (From the Department of Internal Medicine, Yale University School of Medicine, \\ Nerw Haven, Conn.)
}

(Submitted for publication December 19, 1960; accepted January 19, 1961)

The deleterious influence of sodium depletion upon circulatory efficiency and renal function is well known (1-5). Glomerular filtration rate and renal blood flow are generally decreased, sodium excretion declines to the vanishing point, and the ability to excrete a water load is impaired $(4,6)$. Dilutional hyponatremia, by contrast, is often attended by an increase in glomerular filtration rate and enhanced excretion of sodium $(7,8)$, as well as by some decline in maximal urinary concentration of solutes (9).

The present experiments, carried out on rats, were designed to explore the effect of hyponatremia induced by the removal of body sodium upon the ability of the kidneys to conserve water and to concentrate the urine maximally. Maximal urinary concentration was not diminished by merely removing sodium from the diet. However, rats depleted of sodium by peritoneal dialysis demonstrated a considerable fall in renal concentrating ability which resulted in striking losses of water from the body and eventual restoration of serum sodium at the expense of the volume of body fluids.

\section{METHODS}

Group I. The effect of a sodium-free diet upon renal concentrating ability. Eight male Sprague-Dawley rats weighing 240 to $290 \mathrm{~g}$ were fed a synthetic diet containing liberal amounts of sodium and were allowed food and water $a d l i b$. for 6 days. At the end of this time, food and water were withheld and $100 \mathrm{mU}$ of vasopressin suspended in peanut oil was injected subcutaneously. Urine was collected under mineral oil for 24 hours and

* Aided by grants from the National Heart Institute (H-834), the American Heart Association and the Lawrence Gelb Foundation. Presented in part to the American Federation for Clinical Research, Atlantic City, N. J., May, 1960.

$\dagger$ During the tenure of a USPHS postdoctoral fellowship.

$\ddagger$ During the tenure of an Advanced Fellowship of the American Heart Association.

§ During tenure as an Established Investigator of the American Heart Association. its osmolality $\left(U_{\max }\right)$ was determined with a Fiske osmometer. The procedure was repeated on the same animals after they had received a diet containing no sodium for 6 days.

Twelve additional rats, weighing 290 to $310 \mathrm{~g}$, were fed a sodium-free diet for 6 days, at the end of which $\mathrm{U}_{\max }$ was determined. A diet containing adequate amounts of sodium was then allowed but, in order to keep the intake of protein and calories constant, only in amounts limited to those the same animal had consumed during its preceding sodium-free period. In this way each rat served as its own pair-fed control. After 6 days $\mathrm{U}_{\max }$ was again measured.

Group II. The effect of severe hyponatremia upon renal concentrating ability. Nineteen rats (group IIa), weighing 375 to $425 \mathrm{~g}$, were placed on a sodium-free diet. Subsequently a stainless steel cannula of the type described by Kolff and Page (10), was sewn into the peritoneal cavity of each animal and the operative incision allowed to heal. The rats were then placed in individual metabolism cages so that the intake of food and water and the output of urine could be accurately measured. After 2 days of control observations they were subjected to peritoneal dialysis. The dialysis fluid consisted of 5 per cent glucose in water containing $25 \mathrm{mEq}$ per $\mathrm{L}$ of $\mathrm{NaHCO}_{3}$. (The latter was included to minimize acidosis as a result of losses of bicarbonate from the body during dialysis.) A volume of warmed fluid equal to 10 per cent of the body weight was instilled through the cannula into the peritoneal cavity and withdrawn after 2 hours. The procedure was then repeated. The amount of dialysis fluid removed at the end of the 4 hour period was approximately equal to that instilled. At the conclusion of the dialysis, serum sodium, blood urea nitrogen and hematocrit were determined on $0.5 \mathrm{ml}$ of tail blood. Balance studies were resumed on the following morning. Following dialysis, 8 rats were given daily subcutaneous injections of $100 \mathrm{mU}$ of vasopressin in oil for the remainder of the experiment.

Eight days after dialysis, the animals were sacrificed by aortic exsanguination. The shafts of both femurs were removed, cleaned of marrow and, after drying, analyzed for sodium using a Baird flame photometer. Samples of thigh muscle were dried, extracted with anhydrous ether and analyzed for sodium. Both kidneys were removed, fixed in formalin and examined for morphological changes. Hematocrit, serum sodium, serum $\mathrm{CO}_{2}$ content and blood urea nitrogen (11) were determined. Daily urine samples were analyzed for sodium, calcium (12), urea or total nitrogen, and osmolality. 
TABLE I

Effect of a low sodium diet upon maxima? urinary osmolality

\begin{tabular}{|c|c|c|c|c|c|}
\hline & \multicolumn{2}{|c|}{ Low sodium diet } & \multicolumn{2}{|c|}{ Regular diet } & \multirow{2}{*}{$\begin{array}{c}\mathrm{p} \\
\text { (Low } \\
\text { sodium } \\
\text { vs regular) }\end{array}$} \\
\hline & $\begin{array}{l}\text { Food } \\
\text { intake }\end{array}$ & $\mathrm{U}_{\mathrm{osm}}$ & $\begin{array}{c}\text { Food } \\
\text { intake }\end{array}$ & $\mathrm{U}_{\text {oзm }}$ & \\
\hline & $g$ & $\mathrm{mOsm} / \mathrm{kg}$ & $g$ & $m O s m / k g$ & \\
\hline $\begin{array}{c}\text { Group Ia } \\
\mathrm{n}=8\end{array}$ & $\begin{array}{l}27.5^{*} \\
\pm 1.8\end{array}$ & $\begin{array}{l}2,394 \\
\pm 314\end{array}$ & $\begin{array}{r}33.1 \\
\pm 3.6\end{array}$ & $\begin{array}{l}2,730 \\
\pm 274\end{array}$ & $<0.01$ \\
\hline$\underset{\mathrm{n}=12}{\text { Group }} \mathrm{Ib}$ & $\begin{array}{r}29.6 \\
\pm 4.4\end{array}$ & $\begin{array}{l}2,376 \\
\pm 247\end{array}$ & $\begin{array}{r}29.6 \\
\pm 4.4\end{array}$ & $\begin{array}{l}2,227 \\
\pm 200\end{array}$ & $\mathrm{~N}$ \\
\hline
\end{tabular}

$*$ Mean $\pm \mathrm{SD}$.

Thirteen rats (group IIb) were handled in exactly the same manner as those of group II, save that their dialyzing fluid consisted of 5 per cent glucose containing 140 $\mathrm{mEq}$ per $\mathrm{L}$ of $\mathrm{Na}, 115 \mathrm{mEq}$ per $\mathrm{L}$ of $\mathrm{Cl}$ and $25 \mathrm{mEq}$ per $\mathrm{L}$ of $\mathrm{HCO}_{3}$. Following dialysis, dietary intake of these control animals was limited to the average daily intake of the hyponatremic rats of group IIa.

Group III. The effect of moderate hyponatremia upon renal concentrating ability. Eight rats were treated in the same manner as group IIa, except that the second peritoneal dialysis was omitted.

\section{RESULTS}

Effect of a low-sodium diet upon renal concentrating ability (groups I $a$ and $b$, Table I). Maximal urinary osmolality decreased slightly when rats allowed to eat $a d l i b$. were transferred from a regular to a salt-free diet (group Ia). Pair- feeding experiments (group Ib) indicated that this was the result of diminished food intake rather than an effect of salt restriction per se on the kidney. When the intake of animals eating a regular diet was limited to that ingested on a sodium-free diet, no difference in $U_{\max }$ was apparent. Serum sodium was unaltered by a low-sodium diet.

Effect of severe hyponatremia upon renal concentrating ability (groups IIa and b, Tables II and $I I I)$. As a result of sodium depletion by dialysis, serum sodium fell to an average of $107 \mathrm{mEq}$ per L. Blood urea nitrogen rose to an average of 53 $\mathrm{mg}$ per $100 \mathrm{ml}$ and the hematocrit was elevated. Serum sodium, blood urea and hematocrit remained normal in rats dialyzed against a solution containing $150 \mathrm{mEq}$ per $\mathrm{L}$ of sodium (group IIb).

Following dialysis there was a precipitous weight loss in the hyponatremic animals, amounting by the seventh day to 22 per cent of the original weight. By this time, when the rate of weight loss had diminished and body weight had begun to plateau, the average serum sodium had risen from 107 to $139 \mathrm{mEq}$ per L. Weight loss was not so marked in the control animals, whose serum sodium remained unaltered throughout the experiment (Table II, Figure 1).

Immediately following dialysis, urinary output increased markedly in the hyponatremic animals

TABLE II

Effect of hyponatremia upon weight and body composition

\begin{tabular}{|c|c|c|c|c|c|c|c|c|c|}
\hline & & \multicolumn{2}{|c|}{ Weight } & \multicolumn{2}{|c|}{ Serum $\mathrm{Na}$} & \multicolumn{2}{|c|}{ BUN } & \multirow[b]{2}{*}{ Bone $\mathrm{Na}$} & \multirow{2}{*}{$\begin{array}{l}\text { Hematocrit } \\
\text { Postdialysis }\end{array}$} \\
\hline & & Predialysis & Final & Postdialysis & Final & Postdialysis & Final & & \\
\hline \multirow{2}{*}{\multicolumn{2}{|c|}{$\begin{array}{l}\text { Group IIa } \\
\text { Without vasopressin } \\
n=6\end{array}$}} & \multicolumn{2}{|c|}{$g$} & \multicolumn{2}{|c|}{$m E q / L$} & \multicolumn{2}{|c|}{$m g \%$} & $\begin{array}{l}m E q / 100 \mathrm{~g} \\
\text { dry solids }\end{array}$ & $\%$ \\
\hline & & $\begin{array}{r}398 \\
\pm 22\end{array}$ & $\begin{array}{r}320 \\
\pm 18\end{array}$ & $\begin{array}{r}111 \\
\pm 13\end{array}$ & $\begin{array}{r}139 \\
\pm 8\end{array}$ & $\begin{array}{r}51 \\
\pm 6\end{array}$ & $\begin{array}{r}49 \\
\pm 45\end{array}$ & $\begin{array}{l}0.273 \\
\pm 0.011\end{array}$ & $\begin{array}{r}56 \\
\pm 1\end{array}$ \\
\hline \multicolumn{2}{|c|}{$\begin{array}{l}\text { With vasopressin } \\
\mathrm{n}=8\end{array}$} & $\begin{array}{r}399 \\
\pm 18\end{array}$ & $\begin{array}{r}310 \\
\pm 24\end{array}$ & $\begin{array}{r}106 \\
\pm 6\end{array}$ & $\begin{array}{r}139 \\
\pm 9\end{array}$ & $\begin{array}{r}55 \\
\pm 7\end{array}$ & $\begin{array}{r}44 \\
\pm 23\end{array}$ & $\begin{array}{r}0.275 \\
\pm 0.009\end{array}$ & $\begin{array}{r}53 \\
\pm 6\end{array}$ \\
\hline \multicolumn{2}{|c|}{$\begin{array}{l}\text { Group IIb } \\
\text { Without vasopressin } \\
n=6\end{array}$} & $\begin{array}{r}396 \\
\pm 22\end{array}$ & $\begin{array}{r}348 \\
\pm 21\end{array}$ & $\begin{array}{r}147 \\
\pm 3\end{array}$ & $\begin{array}{r}150 \\
\pm 1\end{array}$ & $\begin{array}{r}19 \\
\pm 5\end{array}$ & $\begin{array}{r}15 \\
\pm 1\end{array}$ & $\begin{array}{r}0.286 \\
\pm 0.006\end{array}$ & $\begin{array}{r}48 \\
\pm 2\end{array}$ \\
\hline \multicolumn{2}{|c|}{$\begin{array}{l}\text { With vasopressin } \\
\mathrm{n}=7\end{array}$} & $\begin{array}{r}397 \\
\pm 22\end{array}$ & $\begin{array}{r}344 \\
\pm 18\end{array}$ & $\begin{array}{r}152 \\
\pm ?\end{array}$ & $\begin{array}{r}147 \\
\pm 2\end{array}$ & $\begin{array}{r}19 \\
\pm 3\end{array}$ & $\begin{array}{r}13 \\
\pm 3\end{array}$ & $\begin{array}{r}0.291 \\
\pm 0.009\end{array}$ & $\begin{array}{r}47 \\
\pm 1\end{array}$ \\
\hline \multirow{2}{*}{$\begin{array}{l}\text { p } \\
\text { IIa vs } \\
\text { IIb }\end{array}$} & No vasopressin & NS & 0.01 & 0.01 & 0.01 & 0.01 & 0.01 & 0.10 & 0.01 \\
\hline & $\begin{array}{l}\text { With vaso- } \\
\text { pressin }\end{array}$ & NS & 0.01 & 0.01 & 0.05 & 0.01 & 0.01 & 0.01 & 0.05 \\
\hline
\end{tabular}



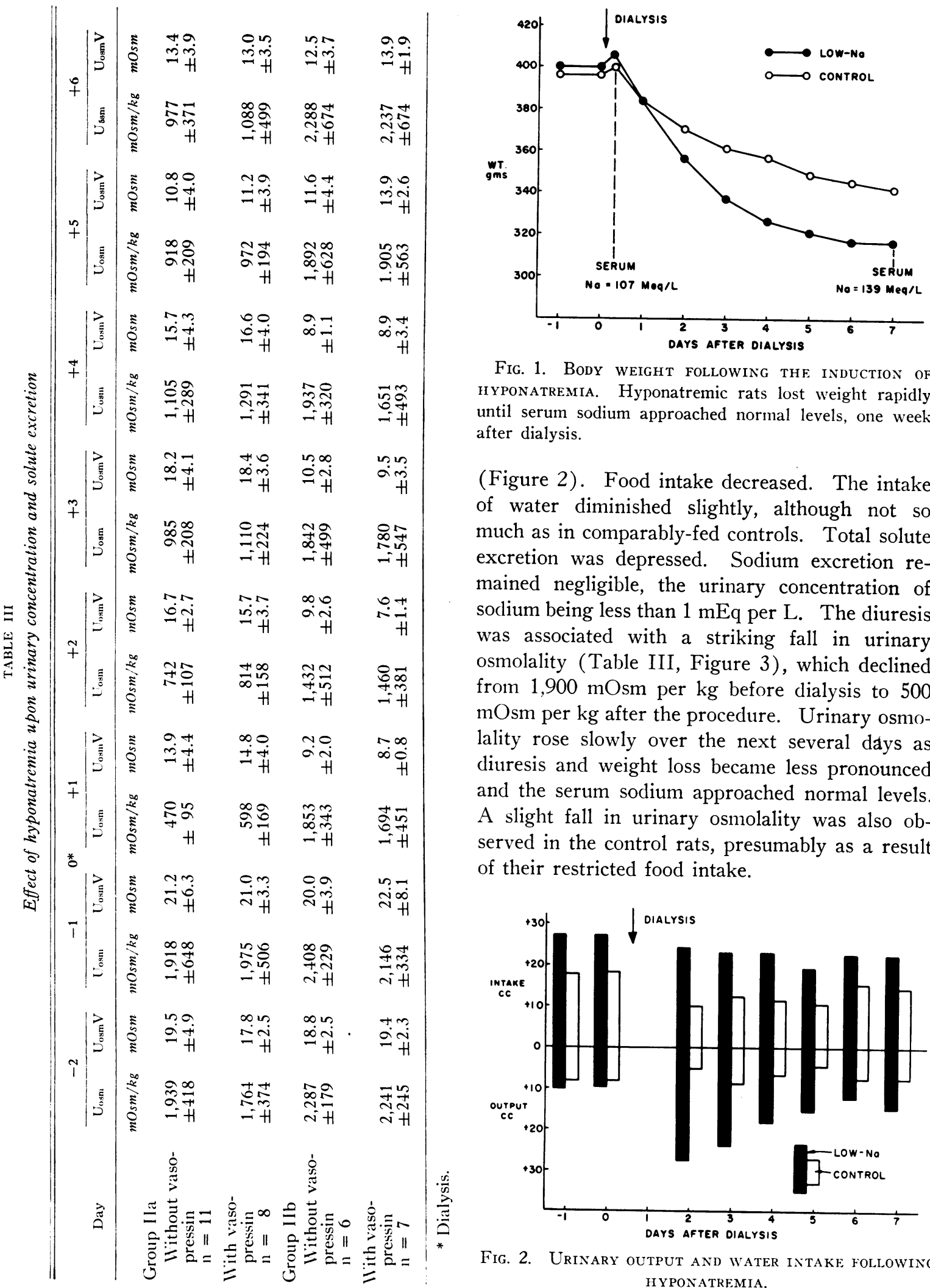

Fig. 1. Body Weight following the induction of HYPONATREMIA. Hyponatremic rats lost weight rapidly until serum sodium approached normal levels, one week after dialysis.

(Figure 2). Food intake decreased. The intake of water diminished slightly, although not so much as in comparably-fed controls. Total solute excretion was depressed. Sodium excretion remained negligible, the urinary concentration of sodium being less than $1 \mathrm{mEq}$ per $\mathrm{L}$. The diuresis was associated with a striking fall in urinary osmolality (Table III, Figure 3), which declined from 1,900 mOsm per $\mathrm{kg}$ before dialysis to 500 $\mathrm{mOsm}$ per $\mathrm{kg}$ after the procedure. Urinary osmolality rose slowly over the next several days as diuresis and weight loss became less pronounced and the serum sodium approached normal levels. A slight fall in urinary osmolality was also observed in the control rats, presumably as a result of their restricted food intake.

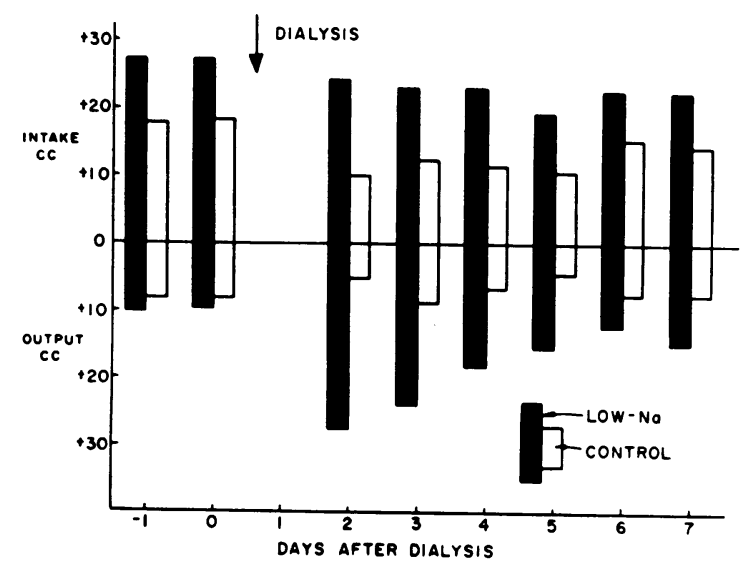

Fig. 2. Urinary output and water intake following HYPONATREMIA. 


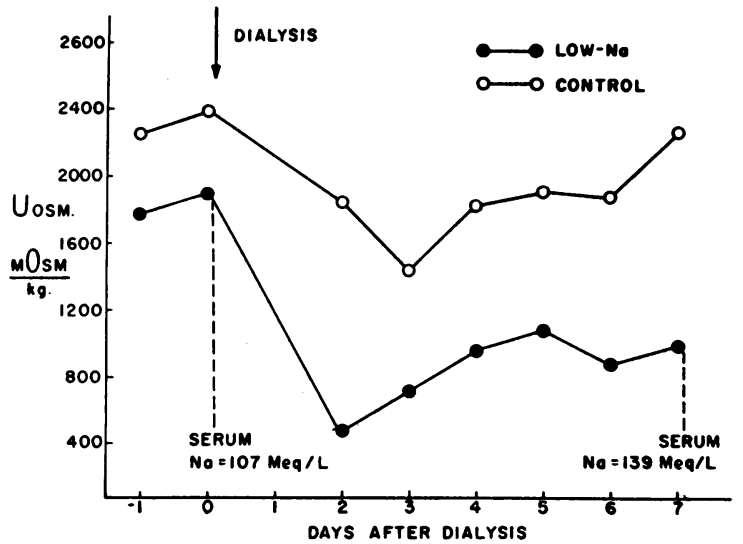

Fig. 3. URinary osmolality following hyponatremia.

The diuresis following sodium depletion was not altered by the daily administration of vasopressin in oil (Figure 4). Vasopressin prevented neither the weight loss nor the marked drop in urinary osmolality associated with hyponatremia. Similar experiments were performed, in which $1,000 \mathrm{mU}$ of aqueous vasopressin was injected subcutaneously every 2 hours for 48 hours after the production of hyponatremia. The postdialysis diuresis was unaffected.

As suggested by other reports $(1,13,14)$, animals depleted of sodium developed a negative nitrogen balance which was more pronounced than that observed in controls (Figure 5). Net urinary losses of potassium in the two groups was similar and proportional to net losses of nitrogen

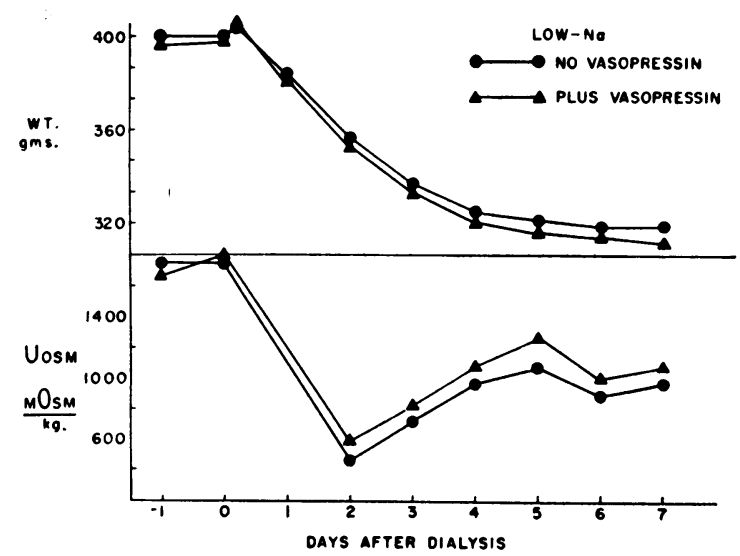

Fig. 4. The efFect of exogenous vasopressin UPON WEIGHT LOSS AND DECREASED URINARY SOLUTE CONCENTRATION ASSOCIATED WITH HYPONATREMIA. Urinary losses of water were not prevented by the administration of vasopressin to hyponatremic rats.

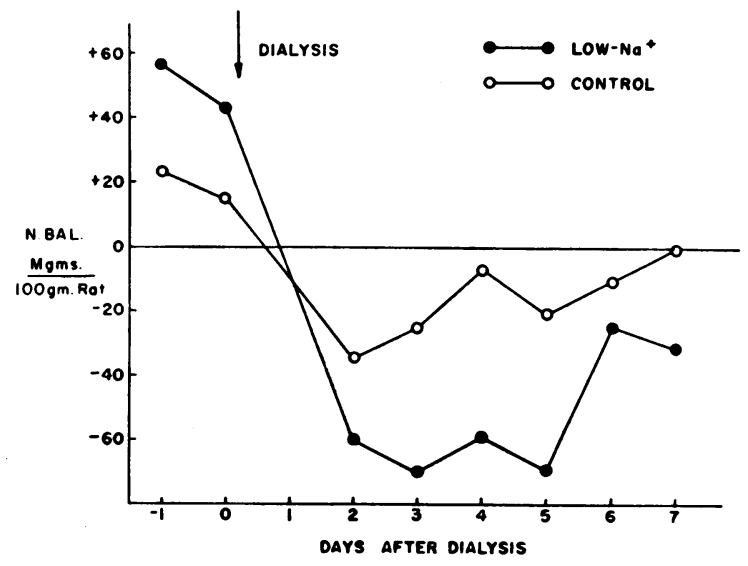

Fig. 5. EFFECT OF HYPONATREMIA UPON NITROGEN BALANCE. Animals depleted of sodium developed a negative nitrogen balance which was more pronounced than that observed in pair-fed controls.

in the approximate ratio of $3 \mathrm{mEq}$ of potassium to $1 \mathrm{~g}$ of nitrogen.

Bone sodium (Table II) was slightly lower in the sodium-depleted animals than in their controls; the losses of sodium from bone, however, were not nearly so striking as those observed in sodium depletion associated with acidosis (15). Urinary calcium excretion and serum calcium levels were unaffected by dialysis, further suggesting that sodium depletion did not result in dissolution of bone. The average muscle sodium in depleted rats at the time of sacrifice was 7.65 $\mathrm{mEq}$ per $100 \mathrm{~g}$ fat-free dry solids (FFDS), compared with $8.23 \mathrm{mEq}$ per $100 \mathrm{~g}$ FFDS in control animals.

Microscopic examination of the kidneys showed severe hydropic changes in the proximal tubules of all animals, with similar though less marked alterations in the distal convoluted tubules. Droplets of eosinophilic material were apparent in the tubular cells in these locations, and eosinophilic material was also present in the lumens of the collecting ducts. This material did not have the staining characteristics of a mucoprotein. Glomeruli, vessels and collecting ducts appeared otherwise normal. The changes in cortical tubules resembled those described by Hamburger, Halpern and Funck-Brentano (16) in rabbits with dilutional hyponatremia.

Effect of moderate hyponatremia upon renal concentrating ability (group III, Table IV). After a single dialysis, average serum sodium fell to 
TABLE IV

Effect of moderate sodium depletion upon urinary concentration

\begin{tabular}{|c|c|c|c|c|c|c|c|c|c|}
\hline & \multicolumn{2}{|c|}{ Weight } & \multicolumn{2}{|c|}{ Serum $\mathrm{Na}$} & \multicolumn{2}{|c|}{ BUN } & \multicolumn{3}{|c|}{$\mathrm{U}_{\max }$} \\
\hline & $\begin{array}{l}\text { At di- } \\
\text { alysis }\end{array}$ & $\begin{array}{c}\text { After } \\
7 \text { days }\end{array}$ & $\begin{array}{c}\text { After } \\
\text { dialysis }\end{array}$ & $\begin{array}{l}\text { After } \\
7 \text { days }\end{array}$ & $\begin{array}{c}\text { After } \\
\text { dialysis }\end{array}$ & $\begin{array}{l}\text { After } \\
7 \text { days }\end{array}$ & $\begin{array}{r}\text { Before } \\
\text { dialysis }\end{array}$ & $\begin{array}{l}\text { Day 1 } \\
\text { after } \\
\text { dialysis }\end{array}$ & $\begin{array}{c}\text { Day } 7 \\
\text { after } \\
\text { dialysis }\end{array}$ \\
\hline & \multicolumn{2}{|c|}{$g$} & \multicolumn{2}{|c|}{$m E q / L$} & \multicolumn{2}{|c|}{$m g \%$} & \multicolumn{3}{|c|}{$\mathrm{mOsm} / \mathrm{kg}$} \\
\hline $\begin{array}{l}\text { Group III, } \\
8 \mathrm{Na} \text {-depleted rats }\end{array}$ & $\begin{array}{r}392 \\
\pm 23\end{array}$ & $\begin{array}{r}340 \\
\pm 36\end{array}$ & $\begin{array}{l}135 \\
\pm 0.2\end{array}$ & $\begin{array}{l}159 \\
\pm 2\end{array}$ & $\begin{array}{r}50 \\
\pm 11\end{array}$ & $\begin{array}{r}24 \\
\pm 7\end{array}$ & $\begin{array}{l}2,324 \\
\pm 354\end{array}$ & $\begin{array}{r}885 \\
\pm 168\end{array}$ & $\begin{array}{l}2,604 \\
\pm 451\end{array}$ \\
\hline
\end{tabular}

$135 \mathrm{mEq}$ per $\mathrm{L}$ and blood urea nitrogen rose to $50 \mathrm{mg}$ per $100 \mathrm{ml}$. Maximal urinary osmolality declined, diuresis and weight loss ensued and serum sodium rose, in a manner entirely similar to that observed in the more severely hyponatremic rats of group IIa.

\section{DISCUSSION}

Hyponatremia produced in the rat by depletion of sodium results in a diuresis of urine of relatively low osmolality and negligible sodium concentration, which continues until the serum sodium is returned to normal. The increase in urine flow is not the result of an osmotic diuresis, since solute excretion actually decreases. Nor is it a consequence of diminished secretion of antidiuretic hormone. It is not prevented by injections of vasopressin and is clearly a reflection of a decrease in the ability of the kidneys to concentrate the urine.

A similar decrease in maximal urinary concentration has been observed in dilutional hyponatremia in dogs (9) and man (17). Under these circumstances, there is frequently an increase in glomerular filtration rate or total solute excretion. In the present study, glomerular filtration rate was undoubtedly diminished by sodium depletion, and solute excretion was uniformly decreased. Acute decreases in glomerular filtration reduced maximal urinary concentration in dogs studied by Leaf, Kerr, Wrong and Chatillon (18) and Levinsky, Davidson and Berliner (19). This was associated, however, with a decrease in urine flow, rather than the sustained increase in urinary output which we observed in hyponatremic rats. Other causes of impaired concentrating ability, such as potassium depletion, hypercalcemia and hypercalciuria, were excluded in the present experiments. Lowering the concentration of urinary sodium per se, by feeding a low salt diet, does not appear to change maximal urinary concentration of the rat, in the absence of hyponatremia. ${ }^{1}$

The mechanism of the decrease in concentrating ability induced by hyponatremia is not clear. It seems probable that the interstitial fluid of the renal medulla and papilla of hyponatremic rats is less highly concentrated in sodium than that of normal animals, either because of changes in renal medullary blood flow which reflect profound alterations in the systemic circulation, or because of a depression of active sodium transport by the medullary tubules.

The degree of impairment of renal concentrating ability and its net effect upon body water and the concentration of serum sodium may vary from one species to another and even among individuals. An abrupt diuresis, loss of weight, and rise in serum chloride were observed by Semple in rats depleted of electrolytes by dialysis (22). Darrow and Yannet (13) depleted three dogs of sodium by peritoneal dialysis; in one the serum sodium subsequently rose spontaneously from 129 to 140 $\mathrm{mEq}$ per $\mathrm{L}$ while it was on a salt-free diet, but hyponatremia persisted in the others. In a similar experiment in a dog, reported by Leaf and Mamby (23), serum sodium also remained low and body weight was undiminished. Holmes and Cizek (24) and Cizek, Huang, Semple and Gregersen $(6,25)$ noted an increase in water intake and urinary output in sodium-depleted dogs; serum chloride, however, remained low when the animals were fed a low salt diet after dialysis. Hyponatremia induced in humans by sodium removal over several days commonly persists until salt is supplied (1). We are unaware of any detailed study of the effect of sodium

\footnotetext{
${ }_{1}$ Maximal urinary concentration of dogs (20) and humans (21) is similarly unaffected by a diet low in sodium.
} 
depletion upon renal concentrating ability in human subjects.

It is of interest that the intake of water remained high in sodium-depleted rats even though extracellular tonicity was low, a state of affairs that might have been expected to reduce thirst (26). Presumably, thirst was sustained under these circumstances by a response to contraction of the volume of extracellular fluid and blood or to other alterations in the circulation which may have been caused by hyponatremia.

Restoration of the concentration of sodium in extracellular fluid was accomplished almost entirely by losses of water from the body. The contribution of bone sodium to replacement of sodium deficits was negligible. This finding contrasts with studies in which sodium depletion was associated with acidosis (15) but is in accord with other experiments in rats in which (as in the present study) acidosis was minimized by placing sodium bicarbonate in the solution used for peritoneal dialysis (27).

In addition to other implications, these experiments provide an interesting physiological example of at least one situation in which tonicity is preserved at the expense of body fluid volume. Rats apparently respond to severe hyponatremia by literally shrinking around their available sodium. This does not appear, however, to result from an adaptive reaction of the hypothalamic centers concerned with thirst and the secretion of antidiuretic hormone. It is rather a consequence of severe, reversible impairment of the renal mechanism for concentrating urine and conserving water.

\section{SUM MARY}

1. Rats depleted of sodium and rendered hyponatremic by peritoneal dialysis develop severe, reversible impairment of renal concentrating ability, resulting in increased urinary losses of water, rapid weight loss and eventual restoration of serum sodium to the normal range.

2. The contribution of bone sodium to replacement of sodium deficits under these circumstances is negligible.

3. Removal of sodium from the diet does not change maximal urinary concentration in the rat if serum sodium is unaltered and protein intake is kept constant.

\section{ACKNOWLEDGMENTS}

The authors are grateful to Dr. Michael Kashgarian of the Department of Pathology, Yale University School of Medicine, for describing and evaluating the changes in renal histology summarized in Results.

Mrs. Eva Taborsky, Mrs. Nadia Myketey and Mrs. Carol Ginter rendered invaluable technical assistance.

\section{REFERENCES}

1. McCance, R. A. Experimental sodium chloride deficiency in man. Proc. roy. Soc. B 1936, 119, 245.

2. Danowski, T. S., Winkler, A. W., and Elkinton, J. R. The treatment of shock due to salt depletion; comparison of the hemodynamic effects of isotonic saline, of hypertonic saline, and of isotonic glucose solutions. J. clin. Invest. 1946, 25, 130.

3. Elkinton, J. R., Danowski, T. S., and Winkler, A. W. Hemodynamic changes in salt depletion and in dehydration. J. clin. Invest. 1946, 25, 120.

4. McCance, R. A., and Widdowson, E. M. The secretion of urine in man during experimental salt deficiency. J. Physiol. (Lond.) 1937, 91, 222.

5. Elkinton, J. R., Winkler, A. W., and Danowski, T. S. The importance of volume and of tonicity of the body fluids in salt depletion shock. J. clin. Invest. 1947, 26, 1002.

6. Cizek, L. J., and Huang, K. C. Water diuresis in the salt-depleted dog. Amer. J. Physiol. 1951, 167, 473.

7. Davis, J. O., Howell, D. S., and Hyatt, R. E. Effect of chronic Pitressin administration on electrolyte excretion in normal dogs and in dogs with experimental ascites. Endocrinology 1954, 55, 499.

8. Leaf, A., Bartter, F. C., Santos, R. F., and Wrong, $O$. Evidence in man that urinary electrolyte loss induced by Pitressin is a function of water retention. J. clin. Invest. 1953, 32, 868.

9. Levinsky, N. G., Davidson, D. G., and Berliner, R. W. Changes in urine concentration during prolonged administration of vasopressin and water. Amer. J. Physiol. 1959, 196, 451.

10. Kolff, W. J., and Page, I. H. Influence of protein and other factors on postnephrectomy hypertension in rats sustained with an improved method of peritoneal lavage. Amer. J. Physiol. 1954, 178, 69.

11. Conway, E. J. Microdiffusion Analysis and Volumetric Error, 4th ed. London, Crosby Lockwood \& Son, 1957.

12. Tisdall, F. F. A note on the Kramer-Tisdall method for the determination of calcium in small amounts of serum. J. biol. Chem. 1923, 56, 439.

13. Darrow, D. C., and Yannet, H. Metabolic studies of the changes in body electrolyte and distribution of body water induced experimentally by deficit of extracellular electrolyte. J. clin. Invest. 1936, $15,419$. 
14. Leaf, A., and Couter, W. T. Evidence that renal sodium excretion by normal human subjects is regulated by adrenal cortical activity. J. clin. Invest. 1949, 28, 1067.

15. Nichols, G., Jr., and Nichols, N. The role of bone in sodium metabolism. Metabolism 1956, 5, 438.

16. Hamburger, J., Halpern, B., and Funck-Brentano, J. L. Une variété d'anurie provoquée par l'hydration excessive des cellules rénales. Presse méd. 1954, 62, 972.

17. Jaenike, J. R., and Waterhouse, C. The effects of sustained vasopressin administration in man. Clin. Res. 1959, 7, 272.

18. Leaf, A., Kerr, W. S., Jr., Wrong, O., and Chatillon, J. Y. Effect of graded compression of the renal artery on water and solute excretion. Amer. J. Physiol. 1954, 179, 191.

19. Levinsky, N. G., Davidson, D. G., and Berliner, R. W. Effects of reduced glomerular filtration on urine concentration in the presence of antidiuretic hormone. J. clin. Invest. 1959, 38, 730.

20. Manitius, A., Levitin, H., and Epstein, F. H. Unpublished data.
21. McCance, R. A. The excretion of urea, salts and water during periods of hydropaenia in man. J. Fhysiol. (Lond.) 1945, 104, 196.

22. Semple, R. E. Compensatory changes in the rat following removal of electrolytes by intraperitoneal dialysis. Amer. J. Physiol. 1952, 168, 55.

23. Leaf, A., and Mamby, A. R. An antidiuretic mechanism not regulated by extracellular fluid tonicity. J. clin. Invest. 1952, 31, 60.

24. Holmes, J. H., and Cizek, L. J. Observations on sodium chloride depletion in the dog. Amer. J. Physiol. 1951, 164, 407.

25. Cizek, L. J., Semple, R. E., Huang, K. C., and Gregersen, M. I. Effect of extracellular electrolyte depletion on water intake in dogs. Amer. J. Physiol. $1951,164,415$.

26. Wolf, A. V. Thirst. Physiology of the Urge to Drink and Problems of Water Lack. Springfield, I11., C. C Thomas, 1958.

27. Winters, R., Whitlock, R. T., DeWalt, J. L., and Welt, L. G. Effect of alterations of the sodium concentration of the serum upon the content of sodium in bone. Amer. J. Physiol. 1958, 195, 167. 